\title{
Sesquiterpenoids and Norsesquiterpenoids from the Formosan Soft Coral Lemnalia laevis
}

\author{
Ali A. H. El-Gamal, ${ }^{\dagger,}$ E-Ping Chiu,${ }^{\dagger}$ Chia-Hua Li,${ }^{\dagger}$ Shi-Yie Cheng, ${ }^{\dagger}$ Chang-Feng Dai,,${ }^{\S}$ and Chang-Yih Duh*,† \\ Department of Marine Biotechnology and Resources, National Sun Yat-sen University, Kaohsiung, Taiwan, Republic of China, \\ Faculty of Pharmacy, Mansoura University, Egypt, and Institute of Oceanography, National Taiwan University, Taipei, \\ Taiwan, Republic of China
}

Received September 1, 2005

Eight new nornardosinane sequiterpenoids, laevinols $\mathrm{A}-\mathrm{H}(\mathbf{1}-\mathbf{8})$, a new neolemnane sesquiterpenoid, laevinone $\mathrm{A}(\mathbf{9})$, and the previously known $6 \beta$-acetyl- $4 \beta, 5 \beta$-dimethyl-1(10) $\alpha$-epoxy- $2 \beta$-hydroxy-7-oxodecalin (10) and 11,12-dihydroxy-6,10-eremophiladiene (11) were isolated from the methylene chloride solubles of the Formosan soft coral Lemnalia laevis. Their structures were elucidated by extensive spectroscopic analysis, and their cytotoxicity against selected cancer cells was measured in vitro.

The genus Lemnalia has afforded a number of bioactive sesquiterpenes..$^{1-10}$ As part of our search for bioactive substances from marine organisms, the Formosan soft coral Lemnalia laevis Thomson and Dean (Nephtheidae) was studied because the $\mathrm{CH}_{2} \mathrm{Cl}_{2}$ extract showed significant cytotoxicity to A-549 (human lung adenocarcinoma), HT29 (human colon adenocarcinoma), and P-388 (mouse lymphocytic leukemia) cell cultures, as determined by standard procedures. ${ }^{11,12}$ Bioassay-guided fractionation of the methylene chloride solubles of L. laevis resulted in the isolation and characterization of eight new nornardosinane sequiterpenoids, laevinols $\mathrm{A}-\mathrm{H}(\mathbf{1}-\mathbf{8})$, a new neolemnane sesquiterpenoid, laevinone $\mathrm{A}(\mathbf{9})$, and the previously known $6 \beta$-acetyl- $4 \beta, 5 \beta$-dimethyl-1(10) $\alpha$-epoxy- $2 \beta$-hydroxy-7-oxodecalin $(\mathbf{1 0})^{2}$ and 11,12-dihydroxy-6,10-eremophiladiene (11). ${ }^{3}$

\section{Results and Discussion}

The molecular formula of laevinol A (1) was found to be $\mathrm{C}_{15} \mathrm{H}_{22} \mathrm{O}_{4}$ from its HREIMS and ${ }^{13} \mathrm{C}$ NMR data. The DEPT spectrum showed signals for three methyls, three $\mathrm{sp}^{3}$ methylenes, four $\mathrm{sp}^{3}$ methines, one $\mathrm{sp}^{3}$ quaternary carbon, one $\mathrm{sp}^{2}$ methine, and two $\mathrm{sp}^{2}$ quaternary carbons. The ${ }^{1} \mathrm{H}$ and ${ }^{13} \mathrm{C}$ NMR spectra indicated the presence of a secondary methyl at $\delta_{\mathrm{H}} 0.95(3 \mathrm{H}, \mathrm{d}, \mathrm{Me}-13)$ and $\delta_{\mathrm{C}} 15.6\left(\mathrm{CH}_{3}, \mathrm{Me}-\right.$ 13); a tertiary methyl at $\delta_{\mathrm{H}} 1.02(3 \mathrm{H}, \mathrm{s}, \mathrm{Me}-14)$ and $\delta_{\mathrm{C}} 18.0$ $\left(\mathrm{CH}_{3}, \mathrm{Me}-14\right)$; a secondary hydroxyl at $\delta_{\mathrm{H}} 3.99(1 \mathrm{H}, \mathrm{br} \mathrm{s}$, $\mathrm{H}-2)$ and $\delta_{\mathrm{C}} 63.7(\mathrm{CH}, \mathrm{C}-2)$; a secondary formyloxy group at $\delta_{\mathrm{H}} 5.44(1 \mathrm{H}, \mathrm{dt}, J=12.0,5.4 \mathrm{~Hz}, \mathrm{H}-7), 8.04(1 \mathrm{H}, \mathrm{s}$, $\mathrm{OCHO})$ and $\delta_{\mathrm{C}} 71.6(\mathrm{CH}, \mathrm{C}-7), 160.2(\mathrm{CH}, \mathrm{OCHO})$; a methyl ketone at $\delta_{\mathrm{H}} 2.19\left(3 \mathrm{H}, \mathrm{s}, \mathrm{H}_{3}-12\right)$ and $\delta_{\mathrm{C}} 35.4\left(\mathrm{CH}_{3}, \mathrm{C}-12\right)$, 210.5 (qC, C-11); and a trisubstituted olefin at $\delta_{\mathrm{H}} 5.69(1 \mathrm{H}$, $\mathrm{d}, J=4.8 \mathrm{~Hz}, \mathrm{H}-1)$ and $\delta_{\mathrm{C}} 123.9(\mathrm{CH}, \mathrm{C}-1), 143.0$ (qC, C-10). These spectroscopic data, coupled with the determined number of degrees of unsaturation (five), suggested that compound $\mathbf{1}$ is a bicyclic norsesquiterpenoid with secondary hydroxyl, secondary formyloxyl, and methyl ketone groups.

After assignments of all the direct ${ }^{1} \mathrm{H}-{ }^{13} \mathrm{C}$ bondings were made on the basis of the HMQC spectrum, the gross structure of 1 was determined by ${ }^{1} \mathrm{H}-{ }^{1} \mathrm{H}$ COSY and HMBC NMR spectroscopic analysis (Figure 1). The ${ }^{1} \mathrm{H}-{ }^{1} \mathrm{H}$ COSY

* To whom correspondence should be addressed. Tel: 886-7-525-2000, ext. 5036. Fax: 886-7-525-5020. E-mail: yihduh@mail.nsysu.edu.tw.

National Sun Yat-sen University.

* Mansoura University.

$\S$ National Taiwan University.

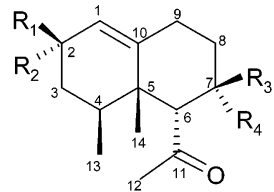

$$
\begin{array}{ll}
1 & R_{1}=H, R_{2}=O H, R_{3}=H, R_{4}=O C H O \\
2 & R_{1}=H, R_{2}=O H, R_{3}=H, R_{4}=O H \\
3 & R_{1}=H, R_{2}=O H, R_{3}=O H, R_{4}=H \\
4 & R_{1}=O H, R_{2}=H, R_{3}=H, R_{4}=O H \\
5 & R_{1}=H, R_{2}=O H, R_{3}, R_{4}=O
\end{array}
$$

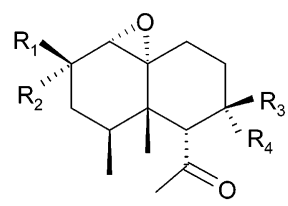

$6 \mathrm{R}_{1}=\mathrm{H}, \mathrm{R}_{2}=\mathrm{OH}, \mathrm{R}_{3}=\mathrm{OH}, \mathrm{R}_{4}=\mathrm{H}$

$7 \mathrm{R}_{1}=\mathrm{OH}, \mathrm{R}_{2}=\mathrm{H}, \mathrm{R}_{3}=\mathrm{OH}, \mathrm{R}_{4}=\mathrm{H}$

$8 \mathrm{R}_{1}=\mathrm{H}, \mathrm{R}_{2}=\mathrm{H}, \mathrm{R}_{3}=\mathrm{OH}, \mathrm{R}_{4}=\mathrm{H}$<smiles>CC(=O)OC1C(=O)CCC2=CC(=O)CC(C)C2(C)C=C1C</smiles>

9<smiles>CC1CCC=C2CCC(C(C)(O)CO)=CC21C</smiles>

11<smiles>CC(=O)C1C(=O)CC[C@]2(O)[C@H](O)CC(O)C12C</smiles>

10 spectrum revealed two partial structures, $\mathbf{a}$ and $\mathbf{b}$ (Figure $1)$. The connectivity between $\mathrm{C}-11$ and $\mathrm{C}-6$ was indicated by the HMBC correlations from $\mathrm{H}-12\left[\delta_{\mathrm{H}} 0.88(3 \mathrm{H}, \mathrm{s})\right]$ to $\mathrm{C}-11\left[\delta_{\mathrm{C}} 213.1(\mathrm{qC})\right]$ and $\mathrm{C}-6[60.8(\mathrm{CH})]$ and from $\mathrm{H}-7\left[\delta_{\mathrm{H}}\right.$ $5.44(1 \mathrm{H}, \mathrm{dt}, J=11.4,5.1 \mathrm{~Hz})]$ to $\mathrm{C}-11$. The HMBC correlation from $\mathrm{H}-13$ to $\mathrm{C}-5\left[\delta_{\mathrm{C}} 35.9(\mathrm{CH})\right]$ comfirmed the connectivity between $\mathrm{C}-4$ and $\mathrm{C}-5$. The HMBC correlations from the proton signal at $\delta 8.04$ to $\mathrm{C}-7$ and from $\mathrm{H}-7$ to the carbon signal at $\delta 160.2$ revealed the location of the secondary formyloxyl group. ${ }^{1}$ The connectivity between partial structures a and $\mathbf{b}$ was exhibited by the HMBC correlations as shown in Figure 1.

The relative stereochemistry of $\mathbf{1}$ was deduced from a 2D NOESY NMR experiment (Table S1, Supporting Infor- 


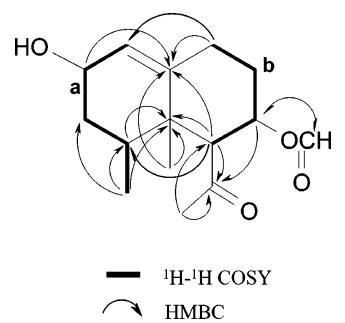

Figure 1. Key COSY and HMBC correlations of $\mathbf{1}$.

mation), which showed that Me-14 (axial), Me-13 (equatorial), H-6 (equatorial), and H-7 (axial) are on $\beta$ face of the molecule, while $\mathrm{H}-4$ (axial) and Me-12 are on the opposite, $\alpha$ face. The $\alpha$-configuration of hydroxy at C-2 was determined by comparison with the $J_{1,2}$ value of lemnacarnol $\left(J_{1,2}=0 \mathrm{~Hz}\right)$ and 2-epi-lemnacarnol $\left(J_{1,2}=4.5 \mathrm{~Hz}\right) .{ }^{1}$ From the aforementioned data, laevinol A could be formulated as $6 \alpha$-acetyl-4 $\beta, 5 \beta$-dimethyl-1(10)-ene-2 $\alpha$-hydroxy- $7 \alpha$-formyloxydecalin.

The HREIMS and ${ }^{13} \mathrm{C}$ NMR data revealed laevinol B (2) to have a molecular formula of $\mathrm{C}_{14} \mathrm{H}_{22} \mathrm{O}_{3}$. The DEPT spectrum showed resonances for three methyls, three $\mathrm{sp}^{3}$ methylenes, four $\mathrm{sp}^{3}$ methines, one $\mathrm{sp}^{3}$ quaternary carbon, one $\mathrm{sp}^{2}$ methine, and two $\mathrm{sp}^{2}$ quaternary carbons. The IR absorptions at 3520 and $1722 \mathrm{~cm}^{-1}$ indicated the presence of hydroxyl and carbonyl groups. The ${ }^{1} \mathrm{H}$ and ${ }^{13} \mathrm{C}$ NMR spectra showed the presence of a secondary methyl at $\delta_{\mathrm{H}}$ $0.95(3 \mathrm{H}, \mathrm{d}, J=6.6 \mathrm{~Hz}, \mathrm{Me}-13)$ and $\delta_{\mathrm{C}} 15.6\left(\mathrm{CH}_{3}, \mathrm{Me}-13\right)$; a tertiary methyl at $\delta_{\mathrm{H}} 1.00(3 \mathrm{H}, \mathrm{s}, \mathrm{Me}-14)$ and $\delta_{\mathrm{C}} 18.2$ $\left(\mathrm{CH}_{3}, \mathrm{Me}-14\right)$; two secondary hydroxyls at $\delta_{\mathrm{H}} 3.97(1 \mathrm{H}, \mathrm{br}$ $\mathrm{s}, \mathrm{H}-2), 4.25(1 \mathrm{H}, \mathrm{dt}, J=11.4,5.1 \mathrm{~Hz}, \mathrm{H}-7)$ and $\delta_{\mathrm{C}} 63.9$ $(\mathrm{CH}, \mathrm{C}-2), 69.0(\mathrm{CH}, \mathrm{C}-7)$; a methyl ketone at $\delta_{\mathrm{H}} 2.34(3 \mathrm{H}$, $\left.\mathrm{s}, \mathrm{H}_{3}-12\right)$ and $\delta_{\mathrm{C}} 36.2\left(\mathrm{CH}_{3}, \mathrm{C}-12\right), 213.1(\mathrm{qC}, \mathrm{C}-11)$; and a trisubstituted olefin at $\delta_{\mathrm{H}} 5.66(1 \mathrm{H}, \mathrm{d}, J=4.5 \mathrm{~Hz}, \mathrm{H}-1)$ and $\delta_{\mathrm{C}} 123.3(\mathrm{CH}, \mathrm{C}-1), 144.0$ (qC, C-10). These spectroscopic data suggested that compound $\mathbf{2}$ is the deformylated derivative of $\mathbf{1}$. The COSY NMR correlations from H-7 to H-6 and H-8 revealed the location of the secondary hydroxyl group at C-7. The relative stereochemistry of $\mathbf{2}$ was established from a 2D NOESY experiment (Table S1, Supporting Information), which showed results similar to those determined from 1 . Therefore, laevinol B was established as $6 \alpha$-acetyl- $4 \beta, 5 \beta$-dimethyl-1(10)-ene-2 $\alpha, 7 \alpha$-dihydroxydecalin.

Laevinol C (3) was assigned a molecular formula of $\mathrm{C}_{14} \mathrm{H}_{22} \mathrm{O}_{3}$, as indicated by its HREIMS and ${ }^{13} \mathrm{C}$ NMR data. The ${ }^{1} \mathrm{H}$ and ${ }^{13} \mathrm{C}$ NMR spectroscopic data resembled those of 2 except for the resonances and splitting patterns in the vicinity of C-7. The relative stereochemistry of $\mathbf{3}$ was deduced from a 2D NOESY experiment (Table S1, Supporting Information). NOESY correlations from Me-14 to $\mathrm{H}-6, \mathrm{H}-9 \beta, \mathrm{H}-8 \beta$, and Me-13 indicated that Me-14 (axial), $\mathrm{Me}-13$ (equatorial), and $\mathrm{H}-6$ (equatorial) are on the $\beta$ face of the molecule, while NOESY correlations from Me-12 to $\mathrm{H}-4$ and from $\mathrm{H}-7$ to $\mathrm{H}-8 \alpha$ suggested that $\mathrm{H}-4$ (axial), $\mathrm{H}-7$ (equatorial), and Me-12 (axial) are on the opposite, $\alpha$ face. Therefore, laevinol $\mathrm{C}$ was determined as $6 \alpha$-acetyl- $4 \beta, 5 \beta$ dimethyl-1(10)-ene-2 $\alpha, 7 \beta$-dihydroxydecalin.

Laevinol D (4) was shown to have the molecular formula $\mathrm{C}_{14} \mathrm{H}_{22} \mathrm{O}_{3}$ by HREIMS and from its ${ }^{13} \mathrm{C}$ NMR data. The ${ }^{1} \mathrm{H}$ and ${ }^{13} \mathrm{C}$ NMR spectra of $\mathbf{4}$ were quite similar to those of $\mathbf{2}$ with the exception of the resonances and splitting patterns in the vicinity of C-2. The configuration of the hydroxy group at C-2 was determined as $\beta$ by comparison with the $J_{1,2}$ value of lemnacarnol $\left(J_{1,2}=0 \mathrm{~Hz}\right)$ and 2-epilemnacarnol $\left(J_{1,2}=4.5 \mathrm{~Hz}\right) .{ }^{1}$ The relative stereochemistry of 4 was deduced from a 2D NOESY experiment (Table S1,
Supporting Information), which exhibited similar results as determined from 1. From the aforementioned data, laevinol $\mathrm{D}$ was formulated as $6 \alpha$-acetyl- $4 \beta, 5 \beta$-dimethyl1 (10)-ene-2 $\beta, 7 \alpha$-dihydroxydecalin.

Laevinol $\mathrm{E}(\mathbf{5})$ gave a molecular formula of $\mathrm{C}_{14} \mathrm{H}_{20} \mathrm{O}_{3}$ from the interpretation of its HREIMS and ${ }^{13} \mathrm{C}$ NMR data. The ${ }^{1} \mathrm{H}$ and ${ }^{13} \mathrm{C}$ NMR spectra of $\mathbf{5}$ were analogous to those of $\mathbf{2}$ and established that the secondary hydroxyl at C-7 in $\mathbf{2}$ was replaced by a ketone in $\mathbf{5}$. The HMBC correlations from $\mathrm{H}-6$ to C-7 and from $\mathrm{H}-8$ to $\mathrm{C}-7$ helped position the ketone carbonyl at C-7. Therefore, laevinol $\mathrm{E}$ was determined as $6 \alpha$-acetyl- $4 \beta, 5 \beta$-dimethyl-1(10)-ene- $2 \alpha$-hydroxy7-oxodecalin.

The molecular formula of laevinol $\mathrm{F}(\boldsymbol{6})$ was found to be $\mathrm{C}_{14} \mathrm{H}_{22} \mathrm{O}_{4}$ from its HREIMS and ${ }^{13} \mathrm{C}$ NMR data. The DEPT spectrum showed the presence of signals for three methyls, three $\mathrm{sp}^{3}$ methylenes, five $\mathrm{sp}^{3}$ methines, two $\mathrm{sp}^{3}$ quaternary carbons, and one $\mathrm{sp}^{2}$ quaternary carbon. The ${ }^{1} \mathrm{H}$ and ${ }^{13} \mathrm{C}$ NMR spectra supported the presence of two secondary hydroxyls at $\delta_{\mathrm{H}} 3.98(1 \mathrm{H}, \mathrm{t}, J=4.2 \mathrm{~Hz}, \mathrm{H}-2), 4.18(1 \mathrm{H}, \mathrm{br}$ $\mathrm{s}, \mathrm{H}-7)$ and $\delta_{\mathrm{C}} 63.6(\mathrm{CH}, \mathrm{C}-2), 67.4(\mathrm{CH}, \mathrm{C}-7)$; a methyl ketone at $\delta_{\mathrm{H}} 2.31\left(3 \mathrm{H}, \mathrm{s}, \mathrm{H}_{3}-12\right)$ and $\delta_{\mathrm{C}} 31.8\left(\mathrm{CH}_{3}, \mathrm{C}-12\right)$, 210.0 (qC, C-11); and a trisubstituted epoxide ring at $\delta_{\mathrm{H}}$ $3.14(1 \mathrm{H}, \mathrm{d}, J=4.2 \mathrm{~Hz}, \mathrm{H}-1)$ and $\delta_{\mathrm{C}} 61.1(\mathrm{CH}, \mathrm{C}-1), 67.4$ (qC, C-10). These data were similar to those of $6 \alpha$-acetyl$4 \beta, 5 \beta$-dimethyl-1(10) $\alpha$-epoxy-2 $\alpha$-hydroxy-7-oxodecalin, but were consistent with the replacement of a ketone at C-7 by a secondary hydroxyl. ${ }^{6}$ The HMBC correlations from H- 6 to C-7 and from H-8 to C-7 enabled the correct positioning of the secondary hydroxyl at C-7. The configurations of the epoxide ring and hydroxyl at C-2 were determined by comparison with the $J_{1,2}$ and $J_{2,3}$ values of $6 \alpha$-acetyl- $4 \beta, 5 \beta$ dimethyl-1(10) $\alpha$-epoxy-2 $\alpha$-hydroxy-7-oxodecalin $\left(J_{1,2}=J_{2,3 \beta}\right.$ $\left.=4.5 \mathrm{~Hz}, J_{2,3 \alpha}=0 \mathrm{~Hz}\right)$ and its 2-epimer. ${ }^{2,13}$ The relative stereochemistry of 6 was deduced from a 2D NOESY experiment (Table S1, Supporting Information), which exhibited results similar to those determined from 3 . From these data, laevinol $\mathrm{F}$ could be formulated as $6 \alpha$-acetyl$4 \beta, 5 \beta$-dimethyl-1(10) $\alpha$-epoxy- $2 \alpha, 7 \beta$-dihydroxydecalin.

Laevinol G (7) was assigned a molecular formula of $\mathrm{C}_{14} \mathrm{H}_{22} \mathrm{O}_{4}$, as indicated by its HREIMS and ${ }^{13} \mathrm{C}$ NMR data. The ${ }^{1} \mathrm{H}$ and ${ }^{13} \mathrm{C}$ NMR spectra of $\mathbf{7}$ were quite similar to those of 6 except for the resonances and splitting patterns in the vicinity of the secondary hydroxyl methine at C-2. The configurations of the epoxy and hydroxy group at C-2/ C-3 were determined by comparison with $J_{1,2}$ and $J_{2,3}$ values of $\mathbf{6}$ and its 2-epimer. ${ }^{2,13}$ The relative stereochemistry of $\mathbf{7}$ was established from a 2D NOESY experiment (Table S1, Supporting Information), which showed results similar to those determined from 6 . Therefore, laevinol G was formulated as $6 \alpha$-acetyl- $4 \beta, 5 \beta$-dimethyl- $1(10) \alpha$-epoxy$2 \beta, 7 \beta$-dihydroxydecalin.

Laevinol $\mathrm{H} \mathrm{(8)}$ was shown to have a molecular formula of $\mathrm{C}_{14} \mathrm{H}_{22} \mathrm{O}_{3}$ by HREIMS and from its ${ }^{13} \mathrm{C}$ NMR data. The ${ }^{1} \mathrm{H}$ and ${ }^{13} \mathrm{C}$ NMR spectroscopic data were similar to those of 7 except for the absence of the C-2 OH. HMBC correlations from $\mathrm{H}-1$ to $\mathrm{C}-2 / \mathrm{C}-3$ and from $\mathrm{H}-4$ to $\mathrm{C}-2 / \mathrm{C}-3$ confirmed the absence of the secondary hydroxyl at C-2. Therefore, laevinol $\mathrm{H}$ was assigned as $6 \alpha$-acetyl- $4 \beta, 5 \beta$ dimethyl-1(10) $\alpha$-epoxy-7 $\beta$-hydroxydecalin.

Laevinone A (9) gave a molecular formula of $\mathrm{C}_{17} \mathrm{H}_{22} \mathrm{O}_{4}$, from its HREIMS and ${ }^{13} \mathrm{C}$ NMR data. The DEPT spectrum showed signals for four methyls, three $\mathrm{sp}^{3}$ methylenes, two $\mathrm{sp}^{3}$ methines, one $\mathrm{sp}^{3}$ quaternary carbon, two $\mathrm{sp}^{2}$ methines, and five $\mathrm{sp}^{2}$ quaternary carbons. Analysis of its ${ }^{1} \mathrm{H},{ }^{13} \mathrm{C}$, ${ }^{1} \mathrm{H}-{ }^{1} \mathrm{H}$ COSY, HMQC, and HMBC NMR spectral data revealed that $\mathbf{9}$ is a neolemnane sesquiterpene ${ }^{3}$ containing 


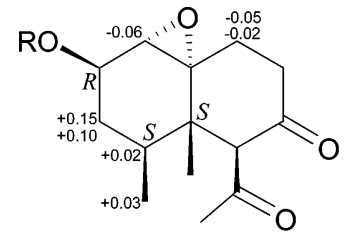

10a $\mathrm{R}=(S)$-MTPA

10b $\mathrm{R}=(R)-\mathrm{MTPA}$

$\Delta \delta=\delta(S)$-MTPA $-\delta(R)$-MTPA $(\mathrm{ppm})$

Figure 2. ${ }^{1} \mathrm{H}$ NMR chemical shift differences $[\delta(S)$-MTPA $-\delta(R)$ MTPA] of the MTPA esters.

a secondary acetoxyl at $\delta_{\mathrm{H}} 5.98(1 \mathrm{H}, \mathrm{s}, \mathrm{H}-4), 2.11(3 \mathrm{H}, \mathrm{s})$ and $\delta_{\mathrm{C}} 76.1(\mathrm{CH}, \mathrm{C}-4), 20.5\left(\mathrm{CH}_{3}\right), 170.0(\mathrm{qC})$; a methylbearing trisubstituted olefin at $\delta_{\mathrm{H}} 5.55(1 \mathrm{H}, \mathrm{s}, \mathrm{H}-2), 1.75$ $(3 \mathrm{H}, \mathrm{s}, \mathrm{Me}-14)$ and $\delta_{\mathrm{C}} 136.9(\mathrm{CH}, \mathrm{C}-2), 129.0$ (qC, C-3), 18.1 $\left(\mathrm{CH}_{3}, \mathrm{C}-14\right)$; a $\beta, \beta$-substituted enone at $\delta_{\mathrm{H}} 6.13(1 \mathrm{H}, \mathrm{s}, \mathrm{H}-9)$ and $\delta_{\mathrm{C}} 128.7(\mathrm{CH}, \mathrm{C}-9), 172.9$ (qC, C-8), 197.6 (qC, C-10); and a secured ketone at $\delta_{\mathrm{C}} 200.6$ (qC, C-5). HMBC NMR correlations from $\mathrm{H}-9\left[\delta_{\mathrm{H}} 6.13(1 \mathrm{H}, \mathrm{s})\right]$ to $\mathrm{C}-10\left[\delta_{\mathrm{C}} 197.6\right.$ $(\mathrm{qC})]$ and $\mathrm{C}-11\left[\delta_{\mathrm{C}} 39.1\left(\mathrm{CH}_{2}\right)\right]$ and from $\mathrm{H}_{2}-11\left[\delta_{\mathrm{H}} 2.38(2 \mathrm{H}\right.$, $\mathrm{m})$ ] to $\mathrm{C}-10$ were used to position the enone at C-8 through $\mathrm{C}-10$. The location of the secondary acetoxy and ketone at C-4, C-5 was demonstrated by HMBC correlations from $\mathrm{H}-4$ $\left[\delta_{\mathrm{H}} 5.98(1 \mathrm{H}, \mathrm{s})\right]$ to $\mathrm{C}-5\left[\delta_{\mathrm{C}} 200.6(\mathrm{qC})\right]$, from $\mathrm{H}-14\left[\delta_{\mathrm{H}} 1.75\right.$ $(3 \mathrm{H}, \mathrm{s})]$ to $\mathrm{C}-4\left[\delta_{\mathrm{C}} 76.1(\mathrm{CH})\right]$, and from $\mathrm{H}_{2}-6\left[\delta_{\mathrm{H}} 2.73(2 \mathrm{H}\right.$, $\mathrm{m})$ ] to $\mathrm{C}-5$. The relative configuration of $\mathbf{9}$ was deduced from a 2D NOESY experiment. NOESY correlations between $\mathrm{H}-2$ and $\mathrm{Me}-13, \mathrm{Me}-14$, and $\mathrm{Me}-15$ indicated that $\mathrm{Me}-13$, $\mathrm{Me}-14, \mathrm{Me}-15$, and $\mathrm{H}-2$ are on the $\beta$ face of the molecule. In turn, a NOESY correlation between $\mathrm{H}-4$ and $\mathrm{H}-12$ suggested that $\mathrm{H}-12$ and $\mathrm{H}-4$ are on the opposite side of the molecule. From the aforementioned data, laevinone A was established as $4\left(S^{*}\right)$-acetoxy-5,10-dioxo, $1\left(S^{*}\right), 12\left(S^{*}\right)$ neolemna-2Z,8-diene.

The spectroscopic and physical data of $\mathbf{1 0}$ were identical with those of $6 \beta$-acetyl- $4 \beta, 5 \beta$-dimethyl-1(10) $\alpha$-epoxy- $2 \beta$ hydroxy-7-oxodecalin ${ }^{2}$ isolated from a soft coral, Lemnalia africana. To determine the absolute configuration, compound 10 was treated with $(R)$ - or $(S)$ - $\alpha$-methoxy- $\alpha$-trifluoromethylphenylacetyl chloride $[(R)$ - or $(S)$-MTPA-Cl] in the presence of pyridine to yield the $(R)$ - and $(S)$-MTPA esters (10b and 10a), respectively. ${ }^{14}$ The MTPA esters formed at C-2 were elucidated from the ${ }^{1} \mathrm{H}$ NMR chemical shifts and coupling constants of $\mathrm{H}-2$ in $\mathbf{1 0 a}$ and $\mathbf{1 0 b}(\mathbf{1 0 a}$, $\delta 5.33,1 \mathrm{H}, \mathrm{t}, J=5.0 \mathrm{~Hz}, \mathrm{H}-2 ; \mathbf{1 0 b}, \delta 5.32,1 \mathrm{H}, \mathrm{t}, J=5.0$ $\mathrm{Hz}, \mathrm{H}-2)$. Comparison of the ${ }^{1} \mathrm{H}$ NMR chemical shifts for 10a and 10b ( $\Delta$ values shown in Figure 2 ) led to the assignment of the $R$-configuration at $\mathrm{C}-2$. Therefore, the absolute structure of this compound was determined as shown in formula $\mathbf{1 0 .}$

Compound $\mathbf{1 1}$ exhibited cytotoxicity against P-388 and HT-29 cell lines with $\mathrm{ED}_{50}$ values of 0.21 and $0.33 \mu \mathrm{g} / \mathrm{mL}$, respectively. The other isolates were not cytotoxic against P-388 and HT-29 cell lines $\left(\mathrm{ED}_{50}>5 \mu \mathrm{g} / \mathrm{mL}\right)$.

\section{Experimental Section}

General Experimental Procedures. Optical rotations were determined on a JASCO DIP-181 polarimeter. IR spectra were recorded on a Hitachi 26-30 spectrophotometer. The NMR spectra were recorded on a Bruker Avance 300 NMR spectrometer at $300 \mathrm{MHz}$ for ${ }^{1} \mathrm{H}$ and 75 for ${ }^{13} \mathrm{C}$ using $\mathrm{CDCl}_{3}$ with TMS as internal standard. EIMS were obtained with a JEOL JMS-SX/SX 102A mass spectrometer at $70 \mathrm{eV}$. Silica gel 60 (Merck, 230-400 mesh) was used for column chromatography; precoated silica gel plates (Merck, Kieselgel $60 \mathrm{~F}_{254}, 0.25 \mathrm{~mm}$ ) were used for TLC analysis.
Animal Material. The soft coral $L$. laevis was collected at Green Island, off Taiwan, in March 2003, at a depth of $3 \mathrm{~m}$ and was stored for 2 weeks in a freezer until extraction. A voucher specimen, NSUGN-062, was deposited in the Department of Marine Biotechnology and Resources, National Sun Yat-sen University, Taiwan.

Extraction and Isolation. The bodies of the soft coral $L$. laevis were freeze-dried to give $1.2 \mathrm{~kg}$ of a solid, which was extracted with $\mathrm{CH}_{2} \mathrm{Cl}_{2}(3.0 \mathrm{~L} \times 3$, overnight for each cycle $)$ at room temperature. After removal of solvent in vacuo, the residue (40 g) was chromatographed over a column containing silica gel 60, using $n$-hexane-EtOAc and $\mathrm{MeOH}-\mathrm{EtOAc}$ mixtures as eluting solvents. Elution by $n$-hexane-EtOAc (65:35) afforded fractions containing $\mathbf{1}$ and $\mathbf{9}$. Elution by $n$-hexane-EtOAc (50:50) afforded fractions containing 2. Elution by $n$-hexane-EtOAc (30:70) afforded fractions containing 7, 10, and 11. Elution by $n$-hexane-EtOAc (1:3) afforded fractions containing $\mathbf{5}$ and $\mathbf{8}$. Elution by EtOAc afforded fractions containing 3, 4, and 6. Compound 1 (4 mg, 0.01\%) was further purified using a RP-C 18 HPLC column, eluting with $\mathrm{MeOH}-\mathrm{H}_{2} \mathrm{O}$ (85:15). Compound 2 (5 mg, 0.01\%) was further purified by silica gel column chromatography, eluting with $\mathrm{MeOH}-\mathrm{CH}_{2} \mathrm{Cl}_{2}$ (98:2). Compound 3 (2 mg, 0.005\%) was further purified by passage over a RP-C 18 HPLC column, eluting with $\mathrm{MeOH}-\mathrm{H}_{2} \mathrm{O}$ (52:48). Compound 4 (3 mg, 0.075\%) was further purified by RP-C 18 HPLC separation, eluting with $\mathrm{MeOH}-\mathrm{H}_{2} \mathrm{O}$ (70:30). Compound 5 (1 mg, 0.0025\%) was further purified using a RP- $\mathrm{C}_{18}$ HPLC column, eluting with $\mathrm{MeOH}-$ $\mathrm{H}_{2} \mathrm{O}$ (63:37). Compound 6 (3 mg, 0.0075\%) was also purified further by $\mathrm{RP}-\mathrm{C}_{18} \mathrm{HPLC}$ separation, eluting with $\mathrm{MeOH}-\mathrm{H}_{2} \mathrm{O}$ (52:48). Compound 7 (1 mg, 0.0025\%) was further purified by silica gel column chromatography, eluting with $\mathrm{MeOH}-\mathrm{CH}_{2} \mathrm{Cl}_{2}$ (95:5). Compound 8 (3 mg, 0.0075\%) was further purified by RP- $\mathrm{C}_{18}$ HPLC separation, eluting with $\mathrm{MeOH}-\mathrm{H}_{2} \mathrm{O}$ (63:37). Compound 9 ( $5 \mathrm{mg}, 0.01 \%$ ) was further purified by silica gel column chromatography, eluting with $\mathrm{MeOH}-\mathrm{CH}_{2} \mathrm{Cl}_{2}$ (85:15). Compound 10 (4 mg, 0.01\%) was further purified by silica gel column chromatography, eluting with $\mathrm{MeOH}-\mathrm{CH}_{2} \mathrm{Cl}_{2}$ (99:1). Finally, compound $\mathbf{1 1}$ (25 mg, 0.05\%) was further purified by silica gel column chromatography, eluting with $n$-hexaneacetone (85:15).

Laevinol A (1): $[\alpha]^{25}{ }_{\mathrm{D}}-173\left(c \quad 0.4, \mathrm{CHCl}_{3}\right)$; IR (neat) $v_{\max }$ $3449,1720 \mathrm{~cm}^{-1} ;{ }^{1} \mathrm{H}$ NMR, see Table $1 ;{ }^{13} \mathrm{C}$ NMR, see Table 2 ; EIMS $m / z 266[\mathrm{M}]^{+}$(5), 248 (9), 202 (10), 176 (15), 232 (10), 201 (12), 173 (18), 160 (100); HREIMS $\mathrm{m} / z 266.1566$ (calcd for $\left.\mathrm{C}_{15} \mathrm{H}_{22} \mathrm{O}_{4}, 266.1569\right)$.

Laevinol B (2): $[\alpha]^{25} \mathrm{D}-132\left(c 0.2, \mathrm{CHCl}_{3}\right)$; IR (neat) $v_{\max }$ 3520, $1722 \mathrm{~cm}^{-1} ;{ }^{1} \mathrm{H}$ NMR, see Table $1 ;{ }^{13} \mathrm{C}$ NMR, see Table 2; EIMS $m / z 238[\mathrm{M}]^{+}(3), 220$ (28), 202 (10), 160 (32), 120 (56), 55 (100); HREIMS $m / z 238.1568$ (calcd for $\mathrm{C}_{14} \mathrm{H}_{22} \mathrm{O}_{3}, 238.1563$ ).

Laevinol C (3): $[\alpha]^{25} \mathrm{D}-98\left(c 0.1, \mathrm{CHCl}_{3}\right)$; IR (neat) $v_{\max }$ 3480, $1718 \mathrm{~cm}^{-1} ;{ }^{1} \mathrm{H}$ NMR, see Table $1 ;{ }^{13} \mathrm{C}$ NMR, see Table 2; EIMS $m / z 238[\mathrm{M}]^{+}$(4), 220 (18), 202 (12); HREIMS $\mathrm{m} / z$ 238.1566 (calcd for $\mathrm{C}_{14} \mathrm{H}_{22} \mathrm{O}_{3}, 238.1563$ ).

Laevinol D (4): $[\alpha]^{25}{ }_{\mathrm{D}}-136\left(c \quad 0.3, \mathrm{CHCl}_{3}\right)$; IR (neat) $v_{\max }$ $3448,1723 \mathrm{~cm}^{-1} ;{ }^{1} \mathrm{H}$ NMR, see Table $1 ;{ }^{13} \mathrm{C}$ NMR, see Table 2 ; EIMS $m / z 238\left[\mathrm{M}^{+}\right.$(6), 220 (23), 202 (7), 160 (22); HREIMS $m / z 238.1560$ (calcd for $\mathrm{C}_{14} \mathrm{H}_{22} \mathrm{O}_{3}, 238.1563$ ).

Laevinol E (5): $[\alpha]^{25}{ }_{\mathrm{D}}-145\left(c 0.1, \mathrm{CHCl}_{3}\right)$; IR (neat) $v_{\max }$ $3520,1725 \mathrm{~cm}^{-1} ;{ }^{1} \mathrm{H}$ NMR, see Table $1 ;{ }^{13} \mathrm{C}$ NMR, see Table 2; EIMS $m / z 236[\mathrm{M}]^{+}(8), 218$ (12), 200 (10); HREIMS $\mathrm{m} / \mathrm{z}$ 236.1403 (calcd for $\mathrm{C}_{14} \mathrm{H}_{20} \mathrm{O}_{3}, 236.1407$ ).

Laevinol F (6): $[\alpha]^{25} \mathrm{D}-76\left(c 0.2, \mathrm{CHCl}_{3}\right)$; IR (neat) $v_{\max }$ 3410, $1718 \mathrm{~cm}^{-1} ;{ }^{1} \mathrm{H}$ NMR, see Table $1 ;{ }^{13} \mathrm{C}$ NMR, see Table 2; EIMS $m / z 254[\mathrm{M}]^{+}(6), 236$ (10), 218 (8), 190 (30), 174 (52), 106 (100); HREIMS m/z 254.1515 (calcd for $\mathrm{C}_{14} \mathrm{H}_{22} \mathrm{O}_{4}, 254.1512$ ).

Laevinol G (7): $[\alpha]^{25}{ }_{\mathrm{D}}-166\left(c 0.3, \mathrm{CHCl}_{3}\right)$; IR (neat) $v_{\max }$ $3509,1722 \mathrm{~cm}^{-1} ;{ }^{1} \mathrm{H}$ NMR, see Table $1 ;{ }^{13} \mathrm{C}$ NMR, see Table 2; EIMS m/z 254 [M] $]^{+}$(4), 236 (11), 218 (7), 190 (33), 106 (100); HREIMS $m / z$ 254.1516 (calcd for $\mathrm{C}_{14} \mathrm{H}_{22} \mathrm{O}_{4}, 254.1512$ ).

Laevinol $\mathbf{H}(8)$ : $[\alpha]^{25}{ }_{\mathrm{D}}-82\left(c 0.1, \mathrm{CHCl}_{3}\right)$; IR (neat) $v_{\max }$ $3430,1725 \mathrm{~cm}^{-1}$; ${ }^{1} \mathrm{H}$ NMR, see Table $1 ;{ }^{13} \mathrm{C}$ NMR, see Table 2; EIMS $\mathrm{m} / z 238 \mathrm{[M}^{+}$(8), 220 (12), 202 (9); HREIMS $\mathrm{m} / \mathrm{z}$ 238.1569 (calcd for $\mathrm{C}_{14} \mathrm{H}_{22} \mathrm{O}_{3}, 238.1563$ ). 
Table 1. ${ }^{1} \mathrm{H}$ NMR Spectroscopic Data of Compounds $\mathbf{1}-\mathbf{8}$ in $\mathrm{CDCl}_{3}{ }^{a}$

\begin{tabular}{|c|c|c|c|c|c|c|c|c|}
\hline position & 1 & 2 & 3 & 4 & 5 & 6 & 7 & 8 \\
\hline 1 & $5.69 \mathrm{~d}(4.8)^{b}$ & $5.66 \mathrm{~d}(4.5)$ & $5.68 \mathrm{~d}(4.8)^{b}$ & $5.48 \mathrm{br} \mathrm{s}$ & $5.86 \mathrm{~d}(5.1)$ & $3.14 \mathrm{~d}(4.2)$ & $2.86 \mathrm{br} \mathrm{s}$ & $2.88 \mathrm{~d}(3.6)$ \\
\hline 2 & $3.99 \mathrm{br} \mathrm{s}$ & $3.97 \mathrm{br} \mathrm{s}$ & $3.99 \mathrm{br} \mathrm{s}$ & $4.25 \mathrm{~m}$ & $4.08 \mathrm{br} \mathrm{s}$ & $3.98 \mathrm{t}(4.2)$ & $4.11 \mathrm{t}(7.8)$ & $1.88 \mathrm{~m}, 2.30 \mathrm{~m}$ \\
\hline 3 & $1.52 \mathrm{~m}$ & $1.53 \mathrm{~m}$ & $1.60 \mathrm{~m}$ & $1.35 \mathrm{~m}, 1.74 \mathrm{~m}$ & $1.65 \mathrm{~m}$ & $\begin{array}{l}1.36 \mathrm{~m} \\
1.58 \mathrm{~m}\end{array}$ & $\begin{array}{l}1.31 \mathrm{~m} \\
1.78 \mathrm{~m}\end{array}$ & $1.28 \mathrm{~m}$ \\
\hline 4 & $1.85 \mathrm{~m}$ & $1.84 \mathrm{~m}$ & $1.90 \mathrm{~m}$ & $1.65 \mathrm{~m}$ & $2.15 \mathrm{~m}$ & $1.99 \mathrm{~m}$ & $1.86 \mathrm{~m}$ & $1.97 \mathrm{~m}$ \\
\hline 6 & $3.42 \mathrm{~d}(5.4)$ & $3.45 \mathrm{~d}(5.1)$ & $3.28 \mathrm{br} \mathrm{s}$ & $3.40 \mathrm{~d}(5.4)$ & $3.93 \mathrm{~s}$ & $3.07 \mathrm{br} \mathrm{s}$ & $3.00 \mathrm{br} \mathrm{s}$ & $2.97 \mathrm{br} \mathrm{s}$ \\
\hline 7 & $5.44 \mathrm{dt}(12.0,5.4)$ & $4.25 \mathrm{dt}(11.4,5.1)$ & $4.11 \mathrm{br} \mathrm{s}$ & $4.25 \mathrm{~m}$ & & $4.18 \mathrm{br} \mathrm{s}$ & $4.19 \mathrm{br} \mathrm{s}$ & $4.18 \mathrm{~m}$ \\
\hline 8 & $1.89 \mathrm{~m}, 2.03 \mathrm{~m}$ & $1.77 \mathrm{~m}, 2.39 \mathrm{~m}$ & $\begin{array}{l}1.72 \mathrm{~m} \\
1.91 \mathrm{~m}\end{array}$ & $1.77 \mathrm{~m}, 1.95 \mathrm{~m}$ & $\begin{array}{l}2.48 \mathrm{~m} \\
2.85 \mathrm{~m}\end{array}$ & $\begin{array}{l}1.79 \mathrm{~m} \\
2.26 \mathrm{~m}\end{array}$ & $\begin{array}{l}1.83 \mathrm{~m} \\
2.29 \mathrm{~m}\end{array}$ & $1.75 \mathrm{~m}, 2.32 \mathrm{~m}$ \\
\hline 9 & $2.29 \mathrm{~m}, 2.45 \mathrm{~m}$ & $1.90 \mathrm{~m}, 2.24 \mathrm{~m}$ & $\begin{array}{l}2.08 \mathrm{~m} \\
2.20 \mathrm{~m}\end{array}$ & $2.30 \mathrm{~m}, 2.40 \mathrm{~m}$ & $2.65 \mathrm{~m}$ & $\begin{array}{l}2.54 \mathrm{dt}(13.5, \\
4.2) \\
1.05 \mathrm{dt}(13.5, \\
1.5)\end{array}$ & $\begin{array}{l}2.53 \mathrm{dt}(14.4 \\
4.8) \\
1.15 \mathrm{~m}\end{array}$ & $1.01 \mathrm{~m}, 2.53 \mathrm{~m}$ \\
\hline 12 & $2.19 \mathrm{~s}$ & $2.34 \mathrm{~s}$ & $2.24 \mathrm{~s}$ & $2.21 \mathrm{~s}$ & $2.22 \mathrm{~s}$ & $2.31 \mathrm{~s}$ & $2.31 \mathrm{~s}$ & $2.33 \mathrm{~s}$ \\
\hline 13 & $0.95 \mathrm{~d}(6.9)$ & $0.95 \mathrm{~d}(6.6)$ & $0.92 \mathrm{~d}(6.9)$ & $0.96 \mathrm{~d}(6.6)$ & $0.93 \mathrm{~d}(6.9)$ & $0.75 \mathrm{~d}(6.9)$ & $0.78 \mathrm{~d}(6.9)$ & $0.73 \mathrm{~d}(6.6)$ \\
\hline 14 & $1.02 \mathrm{~s}$ & $1.00 \mathrm{~s}$ & $1.17 \mathrm{~s}$ & $1.05 \mathrm{~s}$ & $0.91 \mathrm{~s}$ & $1.31 \mathrm{~s}$ & $1.34 \mathrm{~s}$ & $1.27 \mathrm{~s}$ \\
\hline $\mathrm{OCHO}$ & $8.04 \mathrm{~s}$ & & & & & & & \\
\hline
\end{tabular}

${ }^{a}$ Recorded at $300 \mathrm{MHz}$ (assigned by COSY, HSQC, and HMBC experiments). ${ }^{b} J$ values (in Hz) in parentheses.

Table 2. ${ }^{13} \mathrm{C}$ NMR Spectroscopic Data of Compounds 1-9 in $\mathrm{CDCl}_{3}{ }^{a}$

\begin{tabular}{|c|c|c|c|c|c|c|c|c|c|}
\hline & 1 & 2 & 3 & 4 & 5 & 6 & 7 & 8 & 9 \\
\hline 1 & 123.9 & 123.3 & 122.5 & 126.6 & 124.7 & 61.1 & 61.8 & 58.6 & 45.1 \\
\hline 2 & 63.7 & 63.9 & 63.9 & 67.4 & 63.7 & 63.6 & 64.8 & 21.8 & 136.9 \\
\hline 3 & 35.1 & 35.2 & 35.3 & 36.6 & 35.5 & 35.8 & 34.9 & 24.4 & 129.0 \\
\hline 4 & 29.7 & 29.8 & 29.7 & 34.3 & 28.7 & 27.1 & 26.1 & 29.9 & 76.1 \\
\hline 5 & 42.6 & 41.9 & 40.3 & 42.0 & 46.6 & 37.7 & 37.1 & 38.2 & 200.6 \\
\hline 6 & 57.6 & 60.8 & 63.1 & 60.7 & 74.8 & 62.0 & 62.6 & 63.4 & 43.3 \\
\hline 7 & 71.6 & 69.0 & 67.0 & 69.3 & 202.9 & 67.4 & 67.2 & 67.9 & 29.5 \\
\hline 8 & 26.2 & 30.2 & 29.7 & 30.3 & 37.6 & 27.2 & 27.4 & 27.4 & 172.9 \\
\hline 9 & 29.7 & 30.1 & 26.2 & 29.9 & 31.3 & 25.1 & 24.8 & 25.4 & 128.7 \\
\hline 10 & 143.0 & 144.0 & 145.8 & 140.8 & 141.8 & 67.4 & 63.2 & 63.8 & 197.6 \\
\hline 11 & 210.5 & 213.1 & 210.5 & 212.0 & 205.0 & 210.0 & 207.2 & 208.7 & 42.1 \\
\hline 12 & 35.4 & 36.2 & 32.8 & 35.8 & 33.3 & 31.8 & 30.8 & 31.3 & 39.1 \\
\hline 13 & 15.6 & 15.6 & 15.9 & 15.7 & 15.6 & 15.7 & 15.1 & 16.0 & 20.6 \\
\hline 14 & 18.0 & 18.2 & 20.0 & 19.8 & 18.3 & 18.4 & 18.4 & 18.6 & 18.1 \\
\hline 15 & & & & & & & & & 16.8 \\
\hline OCHO & 160.2 & & & & & & & & \\
\hline \multirow[t]{2}{*}{ OAc } & & & & & & & & & 170.0 \\
\hline & & & & & & & & & 20.5 \\
\hline
\end{tabular}

${ }^{a}$ Recorded at $75 \mathrm{MHz}$ (assigned by DEPT, COSY, HSQC, and HMBC experiments).

Laevinone A (9): $[\alpha]^{25}{ }_{\mathrm{D}}+165\left(c 0.4, \mathrm{CHCl}_{3}\right) ; \mathrm{UV} \lambda_{\max }(\log$ є) $232(3.2) \mathrm{nm}$; IR (neat) $v_{\max } 1724,1667 \mathrm{~cm}^{-1} ;{ }^{1} \mathrm{H}$ NMR $(300$ $\left.\mathrm{MHz} \mathrm{CDCl}_{3}\right) \delta 1.07(3 \mathrm{H}, \mathrm{d}, J=6.6 \mathrm{~Hz}, \mathrm{Me}-15), 1.20(3 \mathrm{H}, \mathrm{s}$, $\mathrm{Me}-13), 1.75(3 \mathrm{H}, \mathrm{s}, \mathrm{Me}-14), 2.11\left(3 \mathrm{H}, \mathrm{s}, \mathrm{OCOCH}_{3}\right), 2.38(2 \mathrm{H}$, $\left.\mathrm{m}, \mathrm{H}_{2}-11\right), 2.40(1 \mathrm{H}, \mathrm{m}, \mathrm{H}-7 \beta), 2.54(1 \mathrm{H}, \mathrm{dq}, J=7.0,2.0 \mathrm{~Hz}$, $\mathrm{H}-12), 2.62(1 \mathrm{H}, \mathrm{m}, \mathrm{H}-7 \alpha), 2.73\left(2 \mathrm{H}, \mathrm{m}, \mathrm{H}_{2}-6\right), 5.55(1 \mathrm{H}, \mathrm{s}, \mathrm{H}-2)$, $5.98(1 \mathrm{H}, \mathrm{s}, \mathrm{H}-4), 6.13(1 \mathrm{H}, \mathrm{s}, \mathrm{H}-9) ;{ }^{13} \mathrm{C}$ NMR, see Table 2 ; EIMS $m / z 290[\mathrm{M}]^{+}$(4), 272 (5), 230 (18), 188 (16), 91 (100); HREIMS $m / z 290.1599$ (calcd for $\mathrm{C}_{17} \mathrm{H}_{22} \mathrm{O}_{4}, 290.1596$ ).

$(\boldsymbol{R})$ - and (S)-MTPA Derivatives of 10. To a solution of compound $10\left(1.0 \mathrm{mg}, 4.0 \times 10^{-3} \mathrm{mmol}\right)$ in pyridine $(0.5 \mathrm{~mL})$ at room temperature was added $(R)$-MTPA-Cl $(2.4 \mathrm{mg}, 1.0 \times$ $10^{-2} \mathrm{mmol}$ ), and the resultant mixture was stirred for $24 \mathrm{~h}$ at room temperature. The reaction mixture was worked up by adding $2 \mathrm{~mL}$ of water. Further purification was performed with a short silica gel column with $\mathrm{CH}_{2} \mathrm{Cl}_{2}$ to give $\mathbf{1 0 b}(0.6 \mathrm{mg})$ as a colorless oil. The $(S)$-MTPA ester $\mathbf{1 0 a}(0.5 \mathrm{mg})$ was prepared in the same way. Selected $\Delta \delta$ values $[\delta(S)-\delta(R)]$ are as follows: $\mathrm{H}-1=-0.06, \mathrm{H}-3 \alpha=+0.10, \mathrm{H}-3 \beta=+0.15, \mathrm{H}-4=$ $+0.02, \mathrm{H}-9 \alpha=-0.02, \mathrm{H}-9 \beta=-0.05, \mathrm{H}_{3}-13=+0.03$.

(S)-MTPA ester of 10: ${ }^{1} \mathrm{H} \mathrm{NMR}\left(\mathrm{CDCl}_{3}, 300 \mathrm{MHz}\right) \delta 0.70$ $\left(3 \mathrm{H}, \mathrm{d}, J=6.9 \mathrm{~Hz}, \mathrm{H}_{3}-13\right), 1.24\left(3 \mathrm{H}, \mathrm{s}, \mathrm{H}_{3}-14\right), 1.45(1 \mathrm{H}, \mathrm{m}$, $\mathrm{H}-3 \alpha), 1.46(1 \mathrm{H}, \mathrm{m}, \mathrm{H}-9 \alpha), 1.70(1 \mathrm{H}, \mathrm{m}, \mathrm{H}-3 \beta), 2.15(1 \mathrm{H}, \mathrm{m}$, $\mathrm{H}-4), 2.22\left(3 \mathrm{H}, \mathrm{s}, \mathrm{H}_{3}-12\right), 2.47(1 \mathrm{H}, \mathrm{s}, \mathrm{H}-9 \beta), 2.50(1 \mathrm{H}, \mathrm{m}, \mathrm{H}-8 \beta)$, $2.76(1 \mathrm{H}, \mathrm{m}, \mathrm{H}-8 \alpha), 3.58(3 \mathrm{H}, \mathrm{OMe}), 3.57(1 \mathrm{H}, \mathrm{s}, \mathrm{H}-1), 3.74$ $(1 \mathrm{H}, \mathrm{s}, \mathrm{H}-6), 5.33(1 \mathrm{H}, \mathrm{t}, J=5.0 \mathrm{~Hz}, \mathrm{H}-2), 7.40-7.65(5 \mathrm{H}$, aromatic $\mathrm{H})$.

(R)-MTPA ester of 10: ${ }^{1} \mathrm{H} \mathrm{NMR}\left(\mathrm{CDCl}_{3}, 300 \mathrm{MHz}\right) \delta 0.67$ $\left(3 \mathrm{H}, \mathrm{d}, J=6.9 \mathrm{~Hz}, \mathrm{H}_{3}-13\right), 1.24\left(3 \mathrm{H}, \mathrm{s}, \mathrm{H}_{3}-14\right), 1.35(1 \mathrm{H}, \mathrm{m}$, $\mathrm{H}-3 \alpha), 1.48(1 \mathrm{H}, \mathrm{m}, \mathrm{H}-9 \alpha), 1.60(1 \mathrm{H}, \mathrm{m}, \mathrm{H}-3 \beta), 2.13(1 \mathrm{H}, \mathrm{m}$,
$\mathrm{H}-4), 2.23\left(3 \mathrm{H}, \mathrm{s}, \mathrm{H}_{3}-12\right), 2.52(1 \mathrm{H}, \mathrm{s}, \mathrm{H}-9 \beta), 2.53(1 \mathrm{H}, \mathrm{m}, \mathrm{H}-8 \beta)$, $2.72(1 \mathrm{H}, \mathrm{m}, \mathrm{H}-8 \alpha), 3.63(1 \mathrm{H}, \mathrm{s}, \mathrm{H}-1), 3.66(3 \mathrm{H}, \mathrm{OMe}), 3.74$ $(1 \mathrm{H}, \mathrm{s}, \mathrm{H}-6), 5.32(1 \mathrm{H}, \mathrm{t}, J=5.0 \mathrm{~Hz}, \mathrm{H}-2), 7.39-7.66(5 \mathrm{H}$, aromatic $\mathrm{H}$ ).

Cytotoxicity Testing. P-388 (mouse lymphocytic leukemia) cells were kindly supplied by J. M. Pezzuto, Department of Medicinal Chemistry and Pharmacognosy, University of Illinois at Chicago; A-549 (human lung adenocarcinoma) and HT-29 (human colon adenocarcinoma) were purchased from the American Type Culture Collection. Cytotoxic assays were carried out according to the procedure described previously. ${ }^{3}$ Three concentrations $(50,5$, and $0.5 \mu \mathrm{g} / \mathrm{mL}$ ) of the tested compounds were used in the cytotoxicity assays.

Acknowledgment. We thank J. M. Pezzuto, formerly of the Department of Medicinal Chemistry and Pharmacognosy, University of Illinois at Chicago, for the provision of P-388 cell lines. This work was supported by grants from the National Science Council and Ministry of Education of Taiwan awarded to C.-Y.D.

Supporting Information Available: NOESY correlations of 1-9 are available free of charge via the Internet at http://pubs.acs.org.

\section{References and Notes}

(1) Bowden, B. F.; Coll, J. C.; Mitchell, S. J.; Skelton, B. W.; White, A. H. Aust. J. Chem. 1980, 33, 2737-2747.

(2) Jurek, J.; Scheuer, P. J. J. Nat. Prod. 1993, 56, 508-513.

(3) Izac, R. R.; Fenical, W.; Tagle, B.; Clardy, J. Tetrahedron 1981, 37, $2569-2573$. 
(4) Tursh, B.; Braekman, J. C.; Daloze, D.; Fritz, P.; Kelecom, A.; Karlsson, R.; Losman, D. Tetrahedron Lett. 1974, 747-750.

(5) Bowden, B. F.; Coll, J. C.; Mitchell, S. J. Aust. J. Chem. 1980, 33 681-684.

(6) Kikuchi, H.; Manda, T.; Kobayashi, K.; Yamada, Y.; Iguchi, K. Chem. Pharm. Bull. 1983, 31, 1086-1088.

(7) Bowden, B. F.; Coll, J. C,; Engelhardt, L. M.; Tapiolas, D. M.; White, A. H. Aust. J. Chem. 1986, 39, 103-121.

(8) Carney, J. R.; Pham, A. T.; Yoshita, W. Y.; Scheuer, P. J. Tetrahedron Lett. 1992, 33, 7115-7118.

(9) Zhang, M.; Long, K.; Wu, H.; Ma, K. J. Nat. Prod. 1994, 57, 155160 .
(10) Zhang, M.; Huang, Z. J. Nat. Prod. 1998, 61, 1300-1301.

(11) Geran, R. I.; Greenberg, N. H.; MacDonald, M. M.; Schumacher, A M.; Abbott, B. J. Cancer Chemother. Rep. 1972, 3, 1-91.

(12) Hou, R.-S.; Duh, C.-Y.; Chiang, M.-Y.; Lin, C.-N. J. Nat. Prod. 1995, $58,1126-1130$

(13) Green, D.; Kashman, Y.; Benayahu, Y. J. Nat. Prod. 1992, 55, 11861196.

(14) Dale, J. A.; Dull, D. L.; Mosher, H. S. J. Org. Chem. 1969, 34 , $2543-2549$.

NP050326R 